\title{
Differential toxicities of albendazole and its two main metabolites to Balb/c 3T3, HepG2, and $\mathrm{FaO}$ lines and rat hepatocytes
}

\author{
Lidia Radko, Maria Minta, Sylwia Stypuła-Trębas \\ ${ }^{1}$ Department of Pharmacology and Toxicology, \\ National Veterinary Research Institute, 24-100 Pulawy, Poland \\ lidia.radko@piwet.pulawy.pl
}

Received: June 28, 2016

Accepted: November 7, 2016

\begin{abstract}
Introduction: The cytotoxicity of anthelmintic agent, albendazole (ABZ) and its two major metabolites, sulfoxide (ABZ$\mathrm{SO}$ ) and sulfone (ABZ-SO $)$, on non-hepatic Balb/c $3 \mathrm{~T} 3$ line, two hepatoma cell lines ( $\mathrm{FaO}, \mathrm{HepG} 2)$, and isolated rat hepatocytes was investigated. Material and Methods: Cell cultures were exposed for 24, 48, and $72 \mathrm{~h}$ to eight concentrations of the

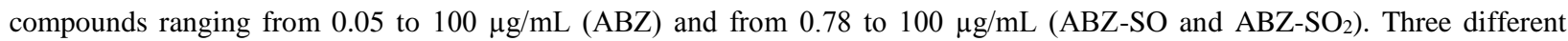
assays were applied in which various biochemical endpoints were assessed: lysosomal activity - neutral red uptake (NRU) assay, proliferation - total protein contents (TPC) assay and lactate dehydrogenase (LDH) leakage assay. Results: The most toxic was albendazole whose $\mathrm{EC}_{50}$ values calculated from the concentration effect curves ranged from 0.2 to $0.5 \mu \mathrm{g} / \mathrm{mL}$ (Balb/c $3 \mathrm{~T} 3$ ) and from 0.4 to $73.3 \mu \mathrm{g} / \mathrm{mL}$ (HepG2). Rat hepatoma line and isolated rat hepatocytes were less sensitive to the impact of ABZ. Toxic action expressed as $\mathrm{EC}_{50}$ was recorded after $72 \mathrm{~h}$ exposure only in $\mathrm{LDH}$ release assay at $0.8 \mu \mathrm{g} / \mathrm{mL}$ and $9.7 \mu \mathrm{g} / \mathrm{mL}$ respectively. The toxicity of metabolites was much lower. The most sensitive to ABZ-SO were fibroblasts and EC50-72h values were similar in all three assays used, i.e. NRU $(14.1 \mu \mathrm{g} / \mathrm{mL})$, TPC $(15.8 \mu \mathrm{g} / \mathrm{mL})$, and LDH $(20.9 \mu \mathrm{g} / \mathrm{mL})$. In the case of $\mathrm{ABZ}_{-\mathrm{SO}_{2}}$ the mean effective concentrations were the highest, and could be reached only in one $\mathrm{LDH}$ assay. These values $(\mu \mathrm{g} / \mathrm{mL})$ were as follows: 65.3 ( FaO), 65.4 (HepG2), 75.8 (hepatocytes), and 77.4 (Balb/c 3T3). Conclusion: The differences in in vitro toxicity of albendazole depend on metabolic ability of the cellular models. Primary cultured rat hepatocytes represent a valuable tool to study the impact of biotransformation on the cytotoxicity of drugs.
\end{abstract}

Keywords: albendazole, metabolites, cytotoxicity, cell cultures.

\section{Introduction}

Usually, veterinary drugs are of public health importance if their residues contaminate the food of animal origin. Such residues can pose the risk to human health when regularly ingested in small amounts (22). Albendazole (ABZ) is a benzimidazole anthelmintic used in humans and animals. It is also used in food-producing animals $(5,13)$. After absorption from the gastrointestinal tract this drug is rapidly metabolised in the liver to sulfoxide (ABZ-SO) and subsequently to sulfone $\left(\mathrm{ABZ}-\mathrm{SO}_{2}\right)$ which are present in blood at higher concentrations than the parent drug. These metabolites can also cumulate in other tissues and are most persistent in the liver, kidneys, and milk (13). Acute toxicity of albendazole in vivo is low; however, in treated animals some adverse effects such as hepatotoxicity and developmental toxicity were observed $(9,13)$. Up to now, there is no consensus as to which compound, $\mathrm{ABZ}$ or its metabolites, is responsible for these adverse effects. Some in vitro studies pointed at $\operatorname{ABZ}(7,12)$, and others at ABZ-SO (8). Studies with the use of zebrafish embryotoxicity test revealed that toxic effects of albendazole were reduced when metabolic deactivation system was applied (18). The fact that anthelmintic benzimidazoles are generally used in domestic animals gives them a high potential to enter the environment. Taking this into account, ABZ was recently classified as 'high' priority for detailed risk assessment (6).

Assuming that toxic effects seen in a whole organism are due to prior failure of basic cellular function, cytotoxicity studies offer a good source of information about the mode of action (mechanism of toxic action), especially if a battery of tests and 
different model systems are used (14-16, 20, 27). The $\mathrm{Balb} / \mathrm{c} 3 \mathrm{~T} 3$ cells are the most frequently used cell line to screen the general toxicity of chemicals. Isolated hepatocytes (2) and liver-derived lines represent the models which are used for evaluation of drugs whose toxicity is mediated through biotransformation $(10,11$, 24, 29).

The aim of this study was to get more insight into the toxicological profile of albendazole at the cellular level.

Three assays were applied to evaluate different parameters of cell damage: NRU, protein, and LDH release. Cell model systems used were nonmetabolising (Balb/c 3T3) line and liver-derived cells with different metabolic capacity i.e. human (HepG2) and rat $(\mathrm{FaO})$ hepatoma cell lines and isolated rat hepatocytes.

\section{Material and Methods}

Drugs and reagents. Analytical standards of albendazole (ABZ, CAS 54965-21-8), albendazole sulfoxide (ABZ-SO, CAS 54029-12-8), and albendazole sulfone (ABZ-SO 2 , CAS 75184-71-3) were purchased from Sigma-Aldrich (USA). Triton X-100, dimethyl sulfoxide (DMSO), foetal bovine serum (FBS), bovine calf serum (BCS), neutral red dye (NR), coomassie brilliant blue R-250 dye, trypsin-EDTA, insulin, hydrocortisone, and antibiotic solution (10.000 $\mathrm{U} / \mathrm{mL}$ of penicillin, $10 \mathrm{mg} / \mathrm{mL}$ of streptomycin) were purchased from Sigma-Aldrich (Poland). All other chemicals were purchased from commercial suppliers and were of the highest available purity.

Cell lines and culture conditions. Balb/c 3T3 clone A31 cell line (gifted by the Department of Swine Diseases, National Veterinary Research Institute in Pulawy) was cultured in Dulbecco`s Modified Eagle`s Medium (DMEM, GIBCO, Paisley, UK). HepG2 cell line was purchased from the American Type Culture Collection (ATCC HB-8065). These cells were cultured in Minimum Essential Medium Eagle (MEME, Sigma-Aldrich (USA). FaO cell line was purchased from the European Collection of Cell Cultures (ECACC 89042701). These cells were cultured in F12 nutrient mixture (Kaighn's modification) (GIBCO, UK). The media were supplemented with $10 \%$ of bovine calf serum (Balb/c 3T3), $10 \%$ of foetal bovine serum (HepG2, FaO), $1 \%$ of L-glutamine, and $1 \%$ of penicillin and streptomycin. The cells were maintained in $75 \mathrm{~cm}^{2}$ cell culture flasks (NUNC) in humidified incubator at $37^{\circ} \mathrm{C}$, in an atmosphere of $5 \% \mathrm{CO}_{2}$. The medium was refreshed every 2 or 3 days and the cells were trypsinised by $0.25 \%$ trypsin-0.02\% EDTA after reaching 70\%-80\% confluence. Single cell suspensions were prepared and adjusted to a density of $2 \times 10^{5}$ cell/ $/ \mathrm{mL}(\mathrm{HepG} 2, \mathrm{FaO})$ for all times of exposure and $1 \times 10^{5}$ cell $/ \mathrm{mL}$ for $24 \mathrm{~h}$, $48 \mathrm{~h}$ exposure or $5 \times 10^{4}$ cell $/ \mathrm{mL}$ for $72 \mathrm{~h}$ exposure (Balb/c 3T3). The cell suspension was transferred to 96-well plates $(100 \mu \mathrm{L} /$ well) and incubated for $24 \mathrm{~h}$ before the exposure to the investigated drugs.

Isolation of hepatocytes and culture condition. Procedure of isolation was carried out in compliance with Bioethical Principles and Permission of Local Bioethical Commission. Wistar albino rats were housed under standard laboratory conditions of lighting (12 h dark/12 h light), temperature $\left(22 \pm 2^{\circ} \mathrm{C}\right)$, and relative humidity $(40 \%-60 \%)$ with free access to commercial feed (Altromin, Spezialfutter, Germany) and tap water. The cells were isolated from the liver of males weighing 250-350g. The two-step collagenase perfusion technique was used, as described previously (25). Hepatocytes were cultured using William's medium $\mathrm{E}$ supplemented with $10 \%$ of foetal bovine serum, $1 \mu \mathrm{M}$ of insulin, $1 \mu \mathrm{M}$ of hydrocortisone, $1 \%$ of glutamine, and $1 \%$ of antibiotics in a humidified incubator at $37^{\circ} \mathrm{C}$, in an atmosphere of $5 \% \mathrm{CO}_{2}$. The cells were seeded on 96-well plates coated with fibronectin (Corning BioCoat, USA) at density of $5 \times$ $10^{5}$ cells/well in $100 \mu \mathrm{L}$ of medium and were incubated until attached. After 4-5 h the medium was replaced with fresh medium containing the investigated drugs.

Exposure and toxicity assessment. Drugs were dissolved in DMSO. The final concentration of DMSO was $0.1 \%$ in the medium. The same final concentration of the solvent was used in the corresponding control. The medium used for test solutions and in control preparation did not contain serum and antibiotics. All drug solutions in medium were freshly prepared and protected from light. The drugs were tested in eight concentrations ranging from 0.05 to $100 \mu \mathrm{g} / \mathrm{mL}$ (for $\mathrm{ABZ}$ ) and from 0.78 to $100 \mu \mathrm{g} / \mathrm{mL}$ (for ABZ-SO and $\mathrm{ABZ}-\mathrm{SO}_{2}$ ). Each concentration was tested in six replicates with three cell generations (cell lines) and in four independent experiments in isolated rat hepatocytes. The viability/cytotoxicity was assessed after 24,48 and $72 \mathrm{~h}$ of exposure. The medium was not changed during the incubation time. The viability/cytotoxicity was assessed using the three assays as described below.

Neutral red uptake (NRU) assay is based on staining of living cells by neutral red which readily diffuses through the plasma membrane and concentrates in lysosomes (3). Following exposure to the drug the medium was removed and the cells were washed with PBS. Then $100 \mu \mathrm{L} /$ well of NR solution $(50 \mu \mathrm{g} / \mathrm{mL})$ was added for $3 \mathrm{~h}$. After this time the cells were washed again with PBS. The dye from viable cells was released by extraction with a mixture of acetic acid, ethanol, and water. After $10 \mathrm{~min}$ of shaking, the absorbance of the dissolved NR was measured at $540 \mathrm{~nm}$ using blank as a reference.

Total protein content (TPC) assay is based upon staining cellular protein (4). After the incubation, the medium containing drug was removed and $100 \mu \mathrm{L}$ of coomassie brilliant blue R-250 dye was added to each well. The plate was shaken for $10 \mathrm{~min}$. Then the stain was removed and the cells were rinsed twice with $100 \mu \mathrm{L}$ of washing solution (glacial acetic acid/ 
ethanol/water). After that the washing solution was replaced with $100 \mu \mathrm{L}$ of the desorbing one (1 M potassium acetate) and the plates were shaken again for $10 \mathrm{~min}$. The absorbance was measured at $595 \mathrm{~nm}$ in microplate reader using blank as a reference.

Lactate dehydrogenase (LDH) assay is based on the assessment of cell membrane damage by measurement of lactate dehydrogenase released into the extracellular media (17). The assay was performed using the commercially available Cytotoxicity Detection Kit (LDH, Roche Diagnostics, Poland) according to the manufacturer's protocol. Triton X-100 was used to determine the maximal LDH content $(100 \%)$ of the cells by allowing complete lysis (positive control).

Data analysis. Viability of cells (\% of control) was expressed as mean $\pm \mathrm{SD}$ (standard deviation) of at least three (cell lines) or four (isolated hepatocytes) independent experiments. One-way analysis of variance (ANOVA) followed by Dunnett's post-hoc test was applied. The values indicating the cytotoxicity concentration $\left(\mathrm{EC}_{50}\right)$ at three time points $(24,48$, and $72 \mathrm{~h}$ ) were calculated according to the Hill's equation (sigmoidal model of concentration-response curve) and expressed as a mean \pm SEM (standard error of mean). Statistical evaluation was performed using ANOVA followed by Tukey's post-hoc test. $\mathrm{P} \leq 0.05$ were considered statistically significant.

\section{Results}

Cell viability, expressed as percentage of nontreated cells (control: $100 \%$ viability) after 24,48 , and $72 \mathrm{~h}$ incubation with ABZ, ABZ-SO, and ABZ-SO $\mathrm{S}_{2}$, is shown in Figs 1-3. The earliest (after $24 \mathrm{~h}$ exposure) significant decrease in viability was observed, depending on the assay and model used, at the concentrations $(\mu \mathrm{g} / \mathrm{mL})$ ranging:

for $\mathrm{ABZ}-0.1-0.5$ (Balb/c 3T3), 0.5-1.0 (HepG2), 0.5-10 (FaO) (Fig.1);

for ABZ-SO - 12.5-25 (Balb/c 3T3), 6.25-50

(HepG2), 6.25-100 (FaO) (Fig. 2);

for $\mathrm{ABZ}-\mathrm{SO}_{2}-12.5-100$ (Balb/c 3T3), 12.5-100

(HepG2), $\geq 100$ (FaO) (Fig.3).

In the case of rat hepatocytes no effects were observed up to the highest concentrations used for ABZ in TPC assay and for both metabolites in NRU and TPC assays (Figs 1-3).

The mean effective cytotoxic concentrations $\left(\mathrm{EC}_{50}\right)$ are shown in Table 1. Out of three tested compounds, the most toxic was albendazole. Very low concentrations of albendazole displayed activity in all three tests and in two lines. $\mathrm{EC}_{50-72 \mathrm{~h}}$ values calculated from the concentration effect curves ranged from 0.2 to $0.3 \mu \mathrm{g} / \mathrm{mL}$ (Balb/c 3T3) and from 0.4 to $62.3 \mu \mathrm{g} / \mathrm{mL}$ (HepG2). The results indicate that higher sensitivity of the assays was after $72 \mathrm{~h}$ exposure compared to 24 and $48 \mathrm{~h}$. Rat hepatoma line and isolated rat hepatocytes were less sensitive to the impact of $\mathrm{ABZ}$. Its toxic action expressed as $\mathrm{EC}_{50}$ was recorded only in $\mathrm{LDH}$ release assay at $72 \mathrm{~h}(0.8 \mu \mathrm{g} / \mathrm{mL}$ and $9.7 \mu \mathrm{g} / \mathrm{mL}$ respectively) (Table 1 ).

The toxicity of metabolites was much smaller and its signs appeared after a longer time of incubation. Only in Balb/c $3 \mathrm{~T} 3$ line, the $\mathrm{EC}_{50-72 \mathrm{~h}}$ values for $\mathrm{ABZ}$ SO could be calculated in all three assays used, i.e. NRU $(14.1 \mu \mathrm{g} / \mathrm{mL})$, TPC $(15.8 \mu \mathrm{g} / \mathrm{mL})$, and $20.9 \mu \mathrm{g} / \mathrm{mL}$ (LDH).

LDH release assay was the only one in which the impact of $\mathrm{ABZ}-\mathrm{SO}_{2}$ was observed. $\mathrm{EC}_{50-72 \mathrm{~h}}$ values $(\mu \mathrm{g} / \mathrm{mL})$ were as follows: $65.3(\mathrm{FaO}), 65.4(\mathrm{HepG} 2)$, 75.8 (hepatocytes), and 77.4 (Balb/c 3T3 cells).

\section{Discussion}

Benzimidazoles produce many biochemical changes of which the primary mode of action is the inhibition of microtubule polymerisation by binding to $\beta$-tubulin $(19,28)$. However, beside the tubulin, other mechanisms have been described including inhibition of tumour growth (21).

In this study cytotoxic potential of albendazole was evaluated in terms of the impact of cell model and assay used, as well as time of exposure. For comparison, ABZ and its two metabolites, $\mathrm{ABZ}-\mathrm{SO}$ and $\mathrm{ABZ}-\mathrm{SO}_{2}$, were tested in separate experiments. Incubation with various concentrations for 24,48 and $72 \mathrm{~h}$ revealed that $\mathrm{ABZ}$ was much more toxic than its metabolites. Out of four models used the most sensitive to ABZ and ABZ-SO were Balb/c $3 \mathrm{~T} 3$ cells. In this cell line the effective concentration $\left(\mathrm{EC}_{50}\right)$ has been achieved in all three assays used and at very low (ABZ) or higher (ABZ-SO) concentrations. There were no significant differences among assays at the corresponding exposure time for $\mathrm{ABZ}$. $\mathrm{EC}_{50}$ values for $\mathrm{ABZ}$ in $\mathrm{HepG} 2$ line were dozens of times higher and time-dependent. In contrast to Balb/c 3T3 cell cultures, significant differences among assays at the corresponding exposure time were noted (Table 1). The most severe effects were observed after $72 \mathrm{~h}$ in $\mathrm{LDH}$ assay. The fact that in $\mathrm{FaO}$ and hepatocyte cultures it was impossible to calculate $\mathrm{EC}_{50}$ value up to the highest concentration used $(100 \mu \mathrm{g} / \mathrm{mL})$ suggests that biotransformation (detoxification) of $\mathrm{ABZ}$ took place. This was further confirmed in our laboratory by chemical analysis of culture supernatants from liver-derived cells in which one or two metabolites were present (unpublished data). No effects of ABZ-SO and $\mathrm{ABZ}-\mathrm{SO}_{2}$ on $\mathrm{HepG} 2, \mathrm{FaO}$, and hepatocytes in neutral red uptake and protein assays were revealed.

To some extent our results are in line with the literature data, which are rather scanty. Previously, Rolin et al. (23) demonstrated that non-metabolising SK-HEP-1 cells were much more susceptible to cytotoxic action of ABZ than HepG2 cells.

According to the author, it was particularly clear that $\mathrm{ABZ}$ was more toxic than the metabolites based on the incapacity of SK-HEP-1 cells to convert ABZ to its less toxic derivatives (23). 

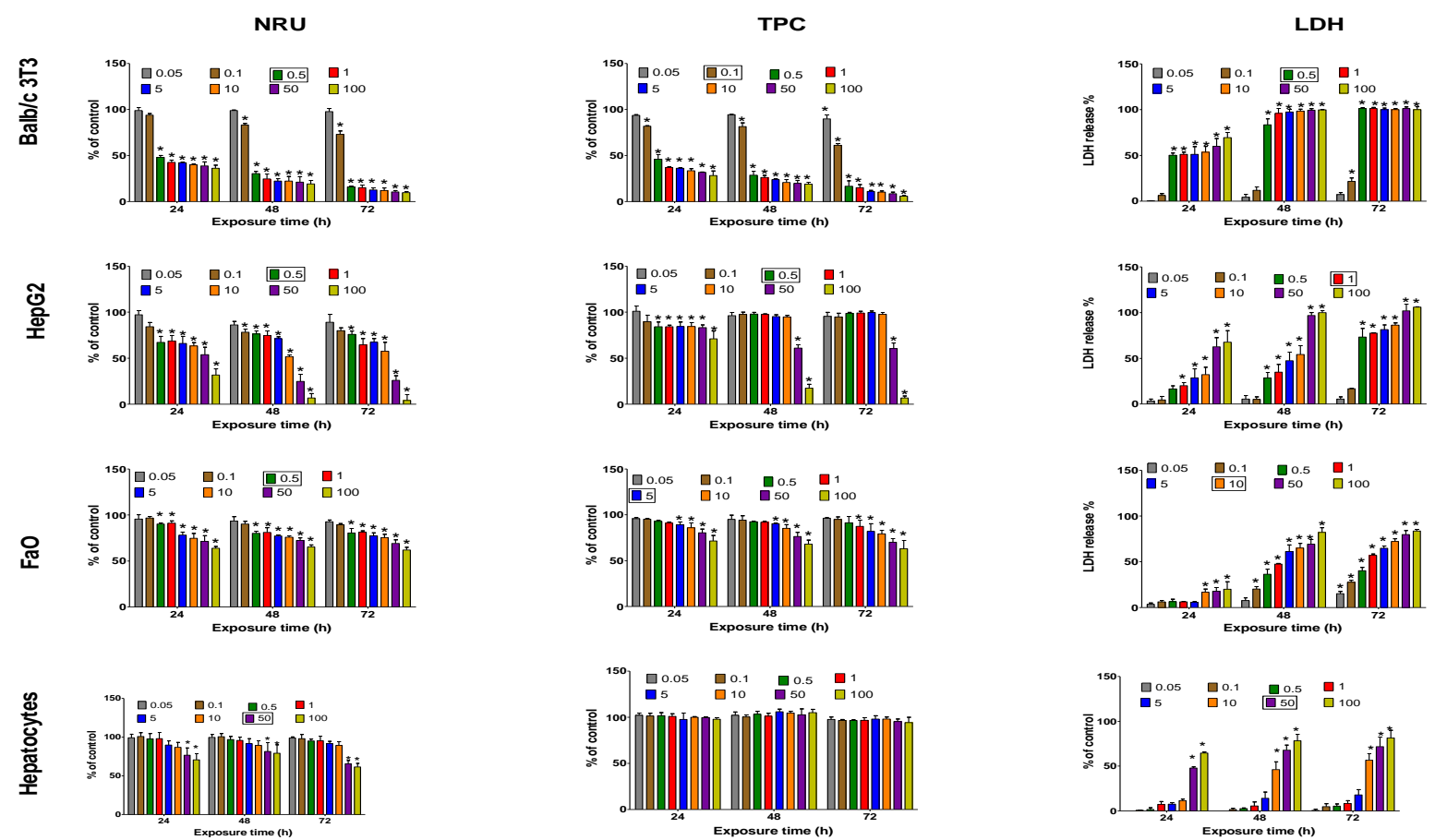

Fig. 1. Concentration- and time-dependent decrease in viability after exposure to albendazole assessed by NRU, TPC, and LDH assays. The results are expressed as mean $\pm \mathrm{SD}$ of three (cell lines) or four (rat hepatocytes) independent experiments. $* \mathrm{P} \leq 0.05$ in comparison with control. The values in frames represent a significant decrease in viability after $24 \mathrm{~h}$ exposure to the drug
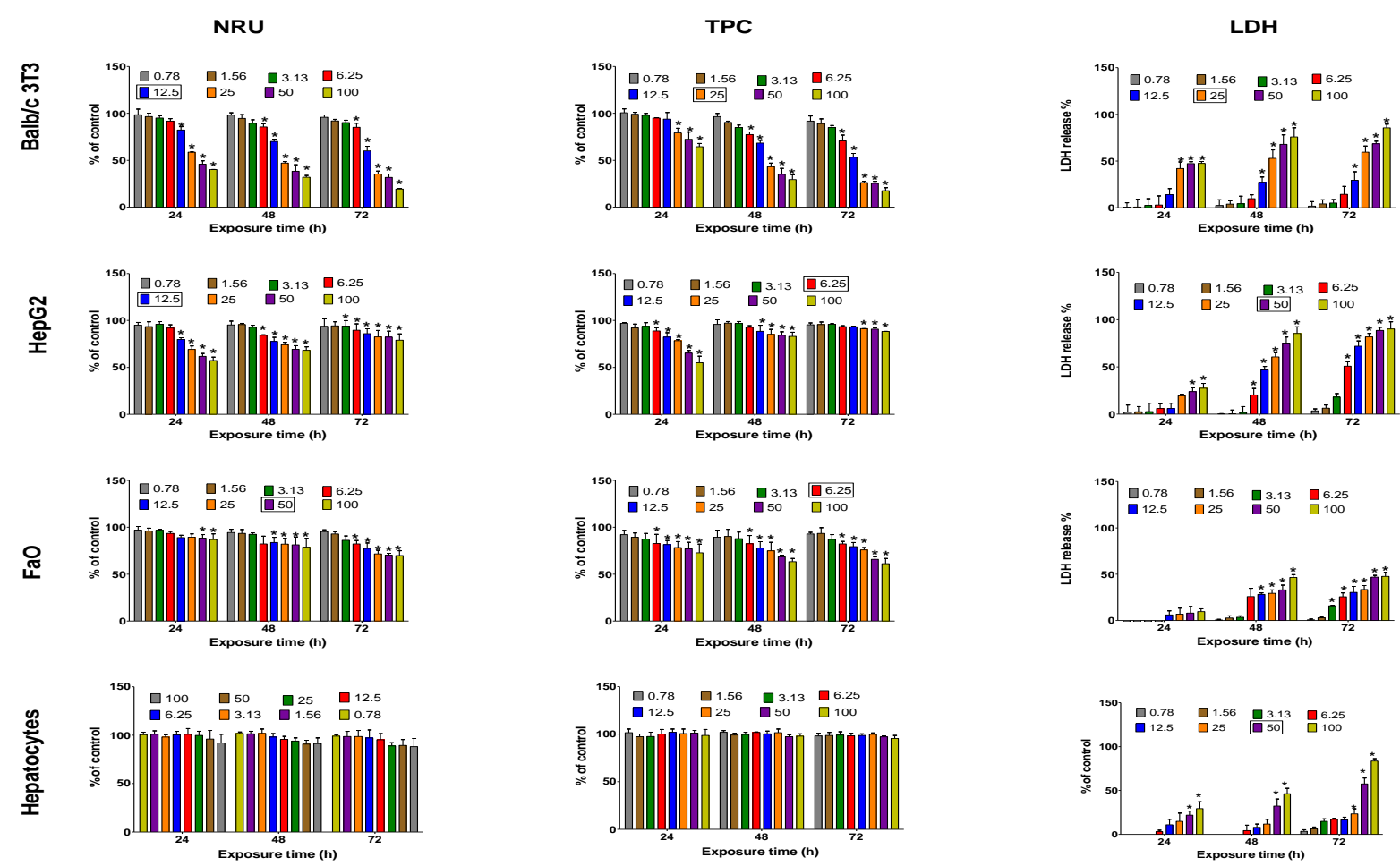

Fig. 2. Concentration- and time-dependent decrease in viability after exposure to albendazole sulfoxide assessed by NRU, TPC, and LDH assays. The results are expressed as mean $\pm \mathrm{SD}$ of three (cell lines) or four (rat hepatocytes) independent experiments. $* \mathrm{P} \leq 0.05$ in comparison with control. The values in frames represent a significant decrease in viability after $24 \mathrm{~h}$ exposure to the drug 



Fig. 3. Concentration- and time-dependent decrease in viability after exposure to albendazole sulfone assessed by NRU, TPC, and LDH assays The results are expressed as mean $\pm \mathrm{SD}$ of three (cell lines) or four (rat hepatocytes) independent experiments. $* \mathrm{P} \leq 0.05$ in comparison with control. The values in frames represent a significant decrease in viability after $24 \mathrm{~h}$ exposure to the drug

Table 1. The effective concentrations $\left(\mathrm{EC}_{50}, \mu \mathrm{g} / \mathrm{mL}\right)$ of drugs determined with NRU, TPC, and LDH assays after 24,48 , and $72 \mathrm{~h}$ exposure. Data are presented as mean $\pm S E M, n=3$ (cell lines) or $\mathrm{n}=4$ (isolated rat hepatocytes)

\begin{tabular}{|c|c|c|c|c|c|c|c|c|c|c|}
\hline \multirow{3}{*}{ Drug } & \multirow{3}{*}{ Cell line } & \multicolumn{9}{|c|}{ Assay } \\
\hline & & \multicolumn{3}{|c|}{ NRU } & \multicolumn{3}{|c|}{ TPC } & \multicolumn{3}{|c|}{ LDH } \\
\hline & & $24 \mathrm{~h}$ & $48 \mathrm{~h}$ & $72 \mathrm{~h}$ & $24 \mathrm{~h}$ & $48 \mathrm{~h}$ & $72 \mathrm{~h}$ & $24 \mathrm{~h}$ & $48 \mathrm{~h}$ & $72 \mathrm{~h}$ \\
\hline \multirow{4}{*}{ No } & Balb/c 3T3 & $\begin{aligned} & 0.5 \\
\pm & 0.1^{\mathrm{aB}}\end{aligned}$ & $\begin{array}{c}0.4 \\
\pm 0.05^{\mathrm{aB}}\end{array}$ & $\begin{array}{c}0.3 \\
\pm 0.03^{\mathrm{aB}}\end{array}$ & $\begin{array}{c}0.5 \\
\pm 0.2^{\mathrm{a}}\end{array}$ & $\begin{array}{c}0.3 \\
\pm 0.09^{\mathrm{aB}}\end{array}$ & $\begin{array}{c}0.2 \\
\pm 0.05^{\mathrm{aB}}\end{array}$ & $\begin{array}{c}0.5 \\
\pm 0.1^{\mathrm{aB}}\end{array}$ & $\begin{array}{c}0.3 \\
\pm 0.04^{\mathrm{aC}}\end{array}$ & $\begin{array}{c}0.2 \\
\pm 0.09^{\mathrm{aA}}\end{array}$ \\
\hline & HepG2 & $\begin{array}{c}59.2 \\
\pm 6.2^{\mathrm{aA}}\end{array}$ & $\begin{array}{c}31.9 \\
\pm 4.8^{\mathrm{aA}}\end{array}$ & $\begin{array}{c}20.9 \\
\pm 3.6^{\mathrm{aA}}\end{array}$ & nd & $\begin{array}{c}73.3 \\
\pm 1.6^{\mathrm{bA}}\end{array}$ & $\begin{array}{c}62.3 \\
\pm 1.6^{\mathrm{bA}}\end{array}$ & $\begin{array}{c}34.1 \\
\pm 3.5^{\mathrm{bA}}\end{array}$ & $\begin{array}{c}9.2 \\
\pm 2.8^{\mathrm{cA}}\end{array}$ & $\begin{array}{c}0.4 \\
\pm 0.1^{\mathrm{cA}}\end{array}$ \\
\hline & $\mathrm{FaO}$ & nd & nd & nd & nd & nd & nd & nd & $\begin{array}{c}2.0 \\
\pm 0.2^{\mathrm{B}}\end{array}$ & $\begin{array}{c}0.8 \\
\pm 0.1^{\mathrm{B}}\end{array}$ \\
\hline & Hepatocytes & nd & nd & nd & nd & nd & nd & $\begin{array}{l}42.2 \\
\pm 2.2^{\mathrm{C}}\end{array}$ & $\begin{array}{c}18.6 \\
\pm 2.8^{\mathrm{C}}\end{array}$ & $\begin{array}{c}9.7 \\
\pm 1.3^{\mathrm{C}}\end{array}$ \\
\hline \multirow{4}{*}{ 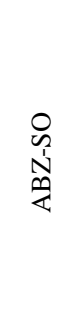 } & Balb/c 3T3 & $\begin{array}{l}32.4 \\
\pm 2.1\end{array}$ & $\begin{array}{l}20.0 \\
\pm 1.5^{\mathrm{a}}\end{array}$ & $\begin{array}{l}14.1 \\
\pm 0.9^{\mathrm{a}}\end{array}$ & nd & $\begin{array}{c}23.7 \\
\pm 1.4^{\mathrm{a}}\end{array}$ & $\begin{array}{l}15.8 \\
\pm 1.1^{\mathrm{a}}\end{array}$ & nd & $\begin{array}{c}23.5 \\
\pm 2.1^{\mathrm{aB}}\end{array}$ & $\begin{array}{c}20.9 \\
\pm 2.1^{\mathrm{bB}}\end{array}$ \\
\hline & HepG2 & nd & nd & nd & nd & nd & nd & nd & $\begin{array}{c}15.4 \\
\pm 2.8^{\mathrm{A}}\end{array}$ & 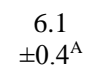 \\
\hline & $\mathrm{FaO}$ & nd & nd & nd & nd & nd & nd & nd & nd & nd \\
\hline & Hepatocytes & nd & nd & nd & nd & nd & nd & nd & nd & $\begin{array}{c}45.1 \\
\pm 1.9^{\mathrm{C}}\end{array}$ \\
\hline \multirow{4}{*}{ 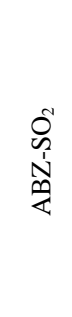 } & Balb/c 3T3 & nd & nd & nd & nd & nd & nd & nd & nd & $\begin{array}{c}77.4 \\
\pm 2.9^{\mathrm{B}}\end{array}$ \\
\hline & HepG2 & $\begin{array}{l}61.7 \\
\pm 3.3\end{array}$ & nd & nd & nd & nd & nd & nd & nd & $\begin{array}{c}65.4 \\
\pm 5.1^{\mathrm{A}}\end{array}$ \\
\hline & $\mathrm{FaO}$ & nd & nd & nd & nd & nd & nd & nd & $\begin{array}{l}48.9 \\
\pm 2.3\end{array}$ & $\begin{array}{c}65.3 \\
\pm 4.1^{\mathrm{A}}\end{array}$ \\
\hline & Hepatocytes & nd & nd & nd & nd & nd & nd & nd & nd & $\begin{array}{c}75.8 \\
\pm 3.9^{\mathrm{B}}\end{array}$ \\
\hline
\end{tabular}

Different small superscript letters (a-c) within lines indicate significant differences among assays at the corresponding exposure time for respective cell line $(\mathrm{P} \leq 0.05)$.

Different capital superscript letters (A-C) within columns indicate significant differences among cell lines at the corresponding time of exposure for respective drug $(\mathrm{P} \leq 0.05)$.

nd - not determined 
Recently, Baliharova et al. (1) investigated the effects of ABZ on cytochrome P450 1A in rat hepatocytes and HepG2 cells. No effects were noted in rat hepatocytes up to the concentration of $50 \mu \mathrm{M}(13.25 \mu \mathrm{g} / \mathrm{mL})$. Conversely, a significant decrease in HepG2 cell viability (up to 30\% compared to control) was detected after 48 and $72 \mathrm{~h}$ incubation with 5 and $50 \mu \mathrm{M}$ (1.325 and 13.25 $\mu \mathrm{g} / \mathrm{mL}$ ) of ABZ (1).

Regarding the methods used in this study, the most sensitive was LDH leakage assay as shown both in the assessment of ABZ and its two metabolites. It means that the target endpoint of damage in all cells (Balb/c 3T3, HepG2, FaO, rat hepatocytes) was disruption of cellular membrane. Cellular damage increased gradually with time and concentration so some alive cells accumulated neutral red.

Our results confirmed the common opinion that compounds which are known to be metabolism-mediated liver toxicants have a differential hepatotoxicity in vitro and that primary cultured rat hepatocytes could represent a valuable tool to study the impact of biotransformation on the cytotoxicity of drugs (26).

Conflict of Interests Statement: The authors declare that there is no conflict of interests regarding the publication of this article.

Financial Disclosure Statement: This work was supported by the project "Comparison of cytotoxicity and metabolism of selected veterinary medicines in hepatoma cell lines (HepG2 and $\mathrm{FaO})$, and isolated rat hepatocytes" conducted within the statutory activity of the National Veterinary Research Institute in Pulawy, Poland.

Animal Rights Statement: The experiment was approved by the Local Ethics Commission (University of Life Sciences in Lublin, Poland).

\section{References}

1. Baliharová V., Skálova L., Maas R.F.M., De Vrieze G., Bull S., Fink-Gremmels J.: The effects of benzimidazole anthelmintics on P4501A in rat hepatocytes and HepG2 cells. Res Vet Sci 2003, 75, 61-69.

2. Blaauboer B.J., Boobis A.R., Castell J.V., Coecke S., Groothuis G.M.M., Guillouzo A., Hall T.J., Hawksworth G.M. Lorenzon G., Miltenburger H.G., Rogiers V., Skett P., Viia P., Wiebel F.J.: The practical applicability of hepatocyte cultures in routine testing. ECVAM Workshop Report 1. ATLA 1994, 22, 231-241.

3. Borenfreund E., Puerner J.A.: Toxicity determined in vitro by morphological alterations and neutral red absorption. Toxicol Lett 1985, 24, 119-124.

4. Bradford M.M.: A rapid and sensitive method for the quantitation of microgram quantities of protein using the principle of dye binding. Anal Biochem 1976, 72, 248-254.

5. Campbell W.C.: Benzimidazoles: veterinary uses. Parasitol Today 1990, 6, 130-133.

6. Capleton A.C., Courage C., Rumsby P., Holmes P., Stutt E., Boxall A.B.A., Levy L.S.: Prioritising veterinary medicines according to their potential indirect human exposure and toxicity profile. Toxicol Lett 2006, 163, 213-223.

7. Carlsson G., Patring J., Ulleras E., Oskarsson A.: Developmental toxicity of albendazole and its three main metabolites in zebrafish embryos. Reprod Toxicol 2011, 32, 129-137.

8. Cristòfol C., Navarro M., Franquelo C., Valladares J.E., Carretero A., Ruberte J., Arboix M.: Disposition of netobimin, albendazole, and its metabolites in the pregnant rat: developmental toxicity. Toxicol Appl Pharmacol 1997, 144, 56-61.

9. Delatour P. Some aspects of the teratogenicity of veterinary drugs. Vet Res Commun 1983, 7, 125-131.

10. Donato M.T., Lahoz A., Castell J.V., Gómez-Lechón M.J.: Cell lines: a tool for in vitro drug metabolism studies. Curr Drug Metab 2008, 9, 1-11.

11. Donato M.T., Jover R., Gómez- Lechón M. J.: Hepatic cell lines for drug hepatotoxicity testing: limitations and strategies to upgrade their metabolic competence by gene engineering. Curr Drug Metab 2013, 14, 946-968.

12. Eckardt K., Kaltenhauser J., Kilb C., Seiler A., Stahlmann R.: Relative potency of albendazole and its sulfoxide metabolite in two in vitro tests for developmental toxicity: the rat whole embryo culture and the mouse embryonic stem cell test. Reprod Toxicol 2012, 34, 378-384.

13. European Medicines Agency (EMEA). 2004. Committee for medicinal products for veterinary use. Albendazole - Summary Report (3). Available from: http://www.emea.eu.int.

14. Fotakis G., Timbrell J.A.: In vitro cytotoxicity assays: Comparison of LDH, neutral red, MTT and protein assay in hepatoma cell lines following exposure to cadmium chloride. Toxicol Lett 2006, 160, 171-177.

15. Gerets H.H.J., Hanon E., Cornet M., Dhalluin S., Depelchin O., Canning M., Atienzar F.A.: Selection of cytotoxicity markers for the screening of new chemical entities in a pharmaceutical context: a preliminary study using a multiplexing approach. Toxicol in Vitro 2009, 23, 319-332.

16. Ivanova L., Uhlig S.: A bioassay for the simultaneous measurement of metabolic activity, membrane integrity, and lysosomal activity in cell cultures. Anal Biochem 2008, 379, 16-19.

17. Korzeniewski C., Calleawert D.M.: An enzyme-release assay for natural cytotoxicity. J Immunol Methods 1983, 64, 313-320.

18. Mattsson A., Ulleras E., Patring J., Oskarsson A.: Albendazole causes stage-dependent developmental toxicity and is deactivated by mammalian metabolization system in a modified zebrafish embryotoxicity test. Reprod Toxicol 2012, 34, 31-42.

19. Martin R.J.: Models of action of anthelmintic drugs. Vet J 1997, 154, 11-34.

20. Pohjala L., Tammela P., Samanta S.K., Yli-Kauhaluoma J., Vuorela P.: Assessing the data quality in predictive toxicology using a panel of cell lines and cytotoxicity assays. Anal Biochem 2007, $362,221-228$.

21. Pourgholami M.H., Woon L., Almajd R., Akhter J., Bowery P., Morris D.L.: In vitro and in vivo suppression of growth of hepatocellular carcinoma cells by albendazole. Cancer Lett 2001, $165,43-49$.

22. Rico A.G., Burgat-Sacaze V.: Veterinary drugs and food safety: a toxicological approach. Rev sci tech Off int Epiz 1985, 4, 111-119.

23. Rolin S., Souhaili-ei Amri H., Batt A.M., Levy M., Baqrel D., Siest G.: Study of the in vitro bioactivation of albendazole in human liver microsomes and hepatoma cell lines. Cell Biol Toxicol 1989, 5, $1-14$.

24. Scheers E.M., Ekwall B., Dierickx P.J.: In vitro long-term cytotoxicity testing of 27 MEIC chemicals on HepG2 cells and comparison with acute human toxicity data. Toxicol in Vitro 2001, 15, 153-161.

25. Seglen P.O.: Preparation of isolation rat liver cells. Methods Cells Biol 1976, 13, 29-83.

26. Wang K., Shindoh H., Inoue T., Horii I.: Advantages of in vitro cytotoxicity testing by using primary rat hepatocytes in comparison with established cell line. J Toxicol Sci 2002, 27, 229-237.

27. Weyermenn J., Lohmann D., Zimmer A.: A practical note on the use of cytotoxicity assays. Int J Pharm 2005, 288, 369-376.

28. Whittaker S.G., Faustman E.M.: Effects of albendazole and albendazole sufoxide on cultures of differentiating rodent embryonic cells. Toxicol Appl Pharmacol 1991, 109, 73-84.

29. Wilk-Zasadna I., Bernasconi C., Pelkonen O., Coecke S.: Biotransformation in vitro: an essential consideration in the quantitative in vitro-to-in vivo extrapolation (QIVIVE) of toxicity data. Toxicology 2015, 332, 8-19. 